\title{
THE POULTRY INDUSTRY IN SWITZERLAND
}

HARALD EBBELL, Oberwangen near Berne, Switzerland Editor of "Der Geflügelhof" and Manager of "Ovomaltine Eierfarm"

During the last years before World War II the Swiss poultry industry severely suffered from dumping prices of imported eggs, Swiss eggs being sold below prime costs in spring and summer. This situation continued until 1941, when egg imports ceased suddenly. The prewar annual imports of 210230 million of eggs dropped then to 164 millions in 1941, 29 millions in 1942, 33 millions in 1943 and to 5 millions in the worst year for foreign supplies: 1944. At the same time-in consequence of the lack of imported grains and animal proteins-poultry stocks went down from the prewar figure of 4.3-4.5 millions to 2.7-2.8 millions, that is about $40 \%$. To secure a just distribution of the reduced home productionforeign eggs not being available-eggs had to be rationed in December 1941. The organization of this egg-rationing which was repealed on March 1, 1946 as the result of Foreign imports, has proved to be quite effective, black market not being of real importance all these years long.

\section{EGG DISTRITBUTION CONTROLLED}

The organization is supervised by the war food office in close connection with the egg co-operative societies, which arranged for egg collecting places in each community. The annual minimum delivery quota has been stipulated at 70 eggs per hen (90 eggs for commercial farms) every poultry keeper having been allowed to keep to himself the eggs of $1 \frac{1 / 2}{2}$ hens per head of people being boarded with him. Instead of eggs, poultry keepers also have the possibility to deliver egg-rationingcoupons got from direct sales to the consumer. In order to stimulate egg deliveries to the community collection places, a price compensation office was founded in 1942, which has the task to reduce the span between producer price and consumer price.

The price compensation office is financed by taxes on imported egg powder and on egg-substitutes. It made possible to reduce the above mentioned price span by $2 \frac{1 / 2}{2}$ Centimes per egg from 5.5 to 3 Centimes and to stabilize the egg price throughout the year at 32 Centimes for deliveries to the collecting places and at 35 Centimes for the consumer.* These

\footnotetext{
* 1 Swiss Franken-100 Centimes-23.2 cents.
} 
official top-prices remained unchanged since 1943 until now, giving to the producer a fair return on his prime costs and protecting the consumer from the black market. Any poultry keeper not fulfilling his annual minimum delivery quota of $\mathbf{7 0}$ (90 eggs for specialized poultry farmers) eggs per hen had to expect a fine and the stoppage of feed-coupons. As mentioned before, this organization proved to be rather an effective one. Producers delivered on an average much more eggs than their minimum delivery quota, namely:

122 eggs or coupons per hen in 1942

135 eggs or coupons per hen in 1943

111 eggs or coupons per hen in 1944

the surplus in part coming from their share of $1 \frac{1}{2}$ hen per head of people living and being boarded with them. With only $60 \%$ of prewar poultry stock, with from year to year poorer quality of feed and with egg imports being insignificant, it has only been possible to give little egg rations on rationing tickets.

The allotments were as follows:

$\begin{array}{ll}\text { Children } & \text { Adults } \\ 36 \text { eggs } & 36 \text { eggs in } 1942 \\ 54 \text { eggs } & 45 \text { eggs in } 1943 \\ 42 \text { eggs } & 31 \text { eggs in } 1944\end{array}$

The prewar yearly consumption was at 150-160 eggs ner head. In addition to fresh eggs it has been possible to improve the rations by imnorted egg powder. which has become free from rationing now.

\section{CULLING AND INSPECTION OF FLOCKS}

To improve poultry keeping and stock, producers not having delivered the demanded 70 (or 90) eggs have been visited during the past three years by officially designated poultry experts, which had been especially instructed for their task. These experts had to cull the birds and advise poultry keepers in order to get more eggs from fewer birds. This action was very successful and from year to year the number of poultry keepers willing to have their birds culled without being forced to, has increased. On an average $20 \%$ of the birds inspected had to be culled; $20 \%$ which only consumed irrecoverable feed without producing eggs! Producers noted soon, that it was worth while to pay to the expert 13-28 Centimes per hen -according to the number of birds to be examined-that is to say not even the equivalent of an egg in order to have much better returns from the remaining hens. 


\section{PRESENT SITUATION}

The present situation of the Swiss poultry industry is about the following:

In contrast with most European countries Switzerland has been able to keep enough quality foundation stock in all breeds of some importance to be able to regain prewar figures in a relatively short time. Also it will be able to help some European countries to restock their breeding plants by exporting high class sires and dams-the first exports of this sort having been executed in fall 1945 to Luxembourg and Czechoslovakia-hatching eggs and day-old chicks in the spring of 1946.

Prices for eggs, poultry, day-old chicks and pullets have been satisfactory during the last three years, but this situation may change in the near future, poultry prices already having dropped seriously and egg prices being supposed to go back as the result of some cheaper imports now expected from Argentine, Denmark and other countries with an intact poultry industry. The efforts of the leading men of the industry tend toward the stabilization of prices for the products of the poultryman at a level, which warrants him a fair return on prime costs.

The feed situation becomes slowly better, having been the worst in summer and fall 1945, when egg production sank to the lowest level ever established because of the lack of grains and animal protein. The feed rationing system favors breeders, placing at their disposal enough feeding stuffs to maintain their valuable stock and to raise pullets for sale. For a time it will not be possible to lift this feed rationing system.

\section{EDUCATION AND RESEARCH WORK}

Education and research of poultry keeping, feeding and breeding is concentrated on the Swiss poultry breeding school at Zollikofen near Berne under the direction of Dr. Hans Engler, who also organized the egg rationing scheme at the war food office. The school-founded 10 years ago-belongs to the Swiss poultry breeding association (S.G.V.), which also maintains there the Swiss laying trial, the office of the inspector of the approved breeding stations and the office of the association itself. The Swiss poultry Journal "Der Geflügelhof"- a weekly magazine, is published by the same association.

The commercial poultry farmers have their own organization, the association of Swiss poultry farmers (V.S.G.F.), with an office at Oberrieden near Zurich. 
For the convenience of readers the following addresses are supplied for contact purposes :

Schweizerische Geflügelzuchtschule, Zollikofen, Berne.

Direktor: Dr. H. Engler.

(The Swiss poultry breeding school, Zollikofen, Berne.)

Schweizerischer Geflügelzuchtverband, S.G.V.

Prasident: E. Mosimann, Riehen bei Basel.

(The Swiss poultry breeding association. S.G.V. President: E. Moismann, Riehen near Basel.)

Verband Schweizerischer Geflügelfarmer. V.S.G.F.

Prasident : E. Duttlinger, ing agr. Neftenback, Zurich.

(The association of Swiss poultry farmers. V.S.G.F.

President : E. Duttlinger, ing. agr. Neftenback, Zurich.)

Verband Schweizerischer Eierverwertungsgenossenschaften, S.E.G.

President: K. Kleb, Kusnacht. Zurich.

(The association of Swiss egg-cooperative-societies.

S.E.G. President: K. Kleb. Kusnacht, Zurich.)

"Der Geflügelhof"

Redaktoren: H. Kuderli, Zollikofen bei Bern.

$\mathrm{H}$. Ebbell, Oberwangen bei Bern.

(The Swiss poultry journal "Der Geflügelhof."

Editors: H. Kuderli, Zollikofen near Berne.

H. Ebbell, Oberwangen near Berne.)

\section{CZECHOSLOVAKIAN LEADERS DESIRE REPRINTS}

Reprints of scientific articles on poultry research are desired by the following:

Prof. Dr. F. Bilek, Chief of the Institute for

Animal Breeding

Prague XIX

Na civicisti 2

Czechoslovakia

Dr. Josef Hlouska, Assoc. Professor, College of

Agriculture and Forestry

Prague XIX

Czechoslovakia

Provincial Institute of Animal Breeding

Brno, Cerna Pole

Czechoslovakia 